\title{
JHAB FOR WHOM? The Radicalization of Religion as a Response to Political Oppression: From Turkish to Indonesian Islam
}

\author{
Olaf Schumann \\ Hamburg University, Germany
}

\begin{abstract}
The confrontation with Western colonialism has become part of the Islamic history since the nineteenth century. This paper is an attempt to investigate the radicalization of religion in several parts of the Islamic world. It focuses, however, on the review of the history of the caliphate and its adjunct notions like "pan-Islamism" or rule over all Muslims, and jihäd to fight for it. Having assessed the attempts made by Muslim in several parts of the Islamic world in dealing with Western colonialism, the paper then reflects the manifestation of Islamic politics in Indonesia. The paper argues that the majority of Muslims whenever they have a chance to voice their aspirations, do not support a radicalization or even militarization of their religion. Muslims in Indonesia, in particular, had this chance to opt for their political or societal aspirations in several general elections, and the large majority of them voted for politicians and parties who pursue an inclusive policy, reflecting the plural composition of their society.
\end{abstract}

Keywords: Jihał, Pan-Islamism, radicalization of religion, inclusive politics.

\section{Introduction}

The movement of Islamic Modernization or Revivalism emerged since the beginning of the 19th century as a response to the social and political experiences made by a great number of the Islamic 
communities all over the world. ${ }^{1}$ The main factor was the confrontation with Western colonialism and, particularly after the Congress of Vienna 1815, the imperialism of the great European powers, particularly Great Britain, Russia, and France. Their counterparts on the Muslim side were at that time still existing Empire of the Moghuls in India, the Persian Kingdom which since 1501 had adopted the Shi ithna $>$ ashariyah as official rite, and the Ottoman Sultanate.

While these Islamic empires, at least during the first half of the $19^{\text {th }}$ century, could maintain their sovereignty, nearly all other areas inhabited by a majority of Muslims like Algiers (1830) and the rest of Northern Africa (except Libya which only in the beginning of the $20^{\text {th }}$ century came under Italian rule), Southeast Asia, Central Asia, parts of Eastern and Western Africa, and finally Northern India (1857), came under imperial rule. The Government of the Kingdom of the Netherlands, established in 1815, took over the former possessions of the Vereeinigde Oostindische Compagnie and expanded its territory. Thus millions of Muslims came under non-Muslim rule.

The responses of the Muslim peoples and leaders were different. In Egypt where Napoleon's invasion only had lasted for 2 years (17981800), a cooperative and constructive attitude could develop, mainly sponsored by the ruler Muhłmmad 'Ali $>$ died 1848), who did not hesitate to invite French and Austrian scholars and experts in different fields of sciences and technology to assist him in building up a modern Egypt. After it was clear that he was the ruler in his country and not a strange king beyond the seas - even the Sultan in Istanbul had to grant him a remarkable amount of independency- the good relationship between him and the foreigners was benefiting both of them, in spite of the cultural and religious otherness which issued not only misunderstandings but also jokes. The interactions between Eastern values and mentalities and Western ways of thinking and behavior underwent their tides throughout the 19th century in Egypt, but at the end of it Egypt emerged as a country on the fringe of modernity. Thus, when the British appeared and imposed their political will on the

\footnotetext{
1 Movements more interested in matters of purifying the doctrines or religious practices, rites or law like those initiated by Shāh Waliyullah ad-Dihlawi (1703-1762) or Muhłmmad 'Abd al-Wahhāb (1703-1787) should be referred to as Puritanism because they were confronting themselves with developments inside the Muslim communities which were not caused by external intervention.
} 
Egyptian rulers, the foundations for a basically positive relationship between Egypt and Europe were already laid, and the conflict centered around the political agenda where, alas, it should cause much damage. That the cultural and social relations between Egypt and Western Europe remained close was to a great deal the merit of Shaykh Muhłmmad 'Abduh (1849-1905) who, after a revolutionary period in his youth under the influence of Jamāl al-Dīn al-Afghāni (see below) and his exile in Beirut and Paris (1882-1889), pursued a moderate but effective reform program especially in the fields of (Islamic) education and law.

Also in India, a positive mutual relationship between the British and the Indians seemed to be a realistic hope. The British (EIC) was centered in Bengal (Calcutta), while the heartland of the main Indian power, the Moghul Empire, was far in the North, its capital being Delhi. Muslim as well as Hindu scholars studied the Western sciences, but also the development of Western societies which enabled them to play the dominant role in world history which became apparent particularly after the Congress of Vienna, the re-empowering of their traditional forms of rule, and their fast expansion supported by their skills in the sciences and technology including their sophisticated weapons which could not be countered by the Eastern peoples. Thus, if these, the Easterners, want to achieve a similar progress and empowerment, they had to learn as much as possible and also to cooperate with the West to reach similar standards. Like in Egypt, there was a basically positive attitude towards the Western culture. Beside a number of Hindu scholars, there were also Muslim intellectuals who supported this understanding, among them Syed Ahmad Khan (1817-98), who later on reformed the Muslim educational system and, among other activities, established the first Muslim university in India (in Aligarh), choosing the English language as the medium of instruction.

The situation, however, changed decisively when the British tried to expand their territory and impose their rule on the Moghuls. The Sepoy troops, actually part of the Moghul sultan's soldiers but put under British military order, rebelled against their British officers, killing some of them. This Mutiny, taking place in 1857, resulted in a ferocious British reaction, vandalizing and destroying, among others, the city of Delhi. 
This date, and the response by the British who finally settled down in a rebuilt "New Delhi," changed the political atmosphere in India decisively, not only among the Muslims but also among the Hindus. In both groups voices emerged and obtained strong support, claiming that for the future it would be unthinkable to cooperate in any way with these barbarians, and that the modernization of India could only be achieved by activating and empowering the own cultural inheritance. Thus cultural, including religious, revival was linked with the demand for political independence.

Not all of the political and intellectual leaders in India, both Muslims and Hindus, supported this call for non-cooperation or even confrontation with the British or, generally speaking, "the West," seeing realistically the distribution of power. Thus, the movements for cultural (and religious) Revival split up into two branches: one being less political and more open for the mental and educational problems of their societies in confronting modernism, the other one seeing its main option in self-reliance and empowering the own cultural and religious inheritance and thus setting a counter-example against the Western paradigm of modernism and progress. For the purpose of this paper, we shall now turn to the "uncooperative" second wing of the Islamic revivalists, and concentrate on the political issues which determined their discourse, in which the Mutiny of 1857 without doubt play an initiating role.

This paper is an attempt to investigate the radicalization of religion in several parts of the Islamic world. It focuses, however, on the review of the history of the caliphate and its adjunct notions like "panIslamism" or rule over all Muslims, and jïhäd to fight for it. Having assessed the attempts made by Muslim in several parts of the Islamic world in dealing with Western colonialism, the paper then reflects the manifestation of Islamic politics in Indonesia.

\section{From Ukbuwwab Islamigab to Pan-Islamism: The Experience of the Ottoman Sultans}

One of the key terms which emerged is that of the ukbumwah Islamizanh, which is usually rendered as "Pan-Islamism"; the Arabic term means "Islamic brotherhood" pointing to the brotherly relationship between the members of the whole Islamic ummah. In history it was closely related to the Caliphate, the caliph as the amir al-mu'minin being the visible symbol of this unity. But the caliphate only covered the political aspect of the unity of the ummah, and in this respect it became 
very weak. Already during the last three centuries of their rule, the Abbasid caliphs lost their power to a number of sultans and other territorial rulers, even competing with other caliphs like the Umayyads in al-Andalus or the Fatimids in Northern Africa. When the Mongols destroyed Baghdad in 1258, the last caliph took refuge in Cairo and maintained there a "shadow caliphate". The Ottoman sultan Selim I (regn. 1512-1520) who conquered Cairo in 1517, took the "shadow caliph" with him to Istanbul. But the former powerful political position of the caliph had lost its meaning. The spiritual dimension of the unity of the ummah found its expression in the common shabadah and the common qiblah, and here as well as in the legal directions, the scholars were the experts. Being successful and powerful, their title as caliph which did not originate in their own traditions did not seem to be of much interest to the Ottoman sultans, and after Süleyman alKanuni (regn. 1520-1566) it hardly was used.

That changed in the beginning of the 19th century when the Ottoman sultans became the target of aggressions and attacks mainly by Russia, which reduced their territory considerably. In this situation, the idea of the caliphate was discovered again, hoping that the whole Muslim ummah would join in solidarity with the caliph in his struggle to maintain his territory, which is part, or even the centre, of Där al-Islam. Thus the notion of the ukhuwwah Islamizath was revived together with the memory of the Caliphate, and both became used by the Ottoman sultans until the end of their rule in 1922, as a political tool to demand support for themselves and their empire.

The appeal of the Ottoman sultans to join them in their defense of their territory being directed to the whole Islamic ummah had, of course, a special impact on those Muslims living now under imperial rule of one or another of the European powers whose religion was Christianity. Thus, the issue of the difference of religion came to new importance, and this opened the door for misunderstandings. For European observers it was difficult to understand that the position of the caliph in the traditional Islamic empire was a legal, albeit a political, position, not a religious one because he had no authority in doctrinal matters. The confusion roots in terminology, because in Islamic usage, "din", usually translated as "religion", covers also those aspects of law which root in the Divine revelation. Therefore, when the caliph is referred to as a "din $\imath$ " authority, Westerners would tend to understand 
that as a religious authority and compare him with the Pope, or as a Patriarch as is known in the Eastern Orthodox churches like in Russia.

This misunderstanding had a fatal impact on the relations with Russia. Immediately after the Ottomans had conquered Constantinople, the capital of the former Byzantine empire which had continued some of the traditions of the ancient Imperium Romanum (and therefore in Arabic and Turkish literature is referred to as "Rūm"; see also Surat al-Rum in the Qur'a the ruler of Moscow emerged as "tsar" (or kaisar), and beside him the Patriarchate of Moscow, continuing the traditions of Byzantium as "the Third Rome". Thus for Russia, the struggle with the Ottomans was not without reminiscence of the former role of Istanbul as Constantinople, and behind the attacks against the Turks was a little hope to reestablish the old glory of Byzantium, or at least take revenge for its defeat. This was a hidden agenda, but not really unperceivable as was felt during the RussianOttoman war of 1877-1878 and the Balkan wars during the beginning of the $20^{\text {th }}$ century in which Russia, inspired by the ideology of PanSlavism, encouraged the Slavic peoples on the Balkan to free themselves from Ottoman supremacy or direct rule.

On the other side, Sultan Abdülhamid II (regn. 1876-1909), seeing the continuous decline of his political power, tried to increase at least his "religious" authority by presenting himself as the caliph, referring to the Ottoman Constitution promulgated in 1876 by himself which states: "The Sultan, as caliph, is the protector of the Islamic Religion." This could be interpreted as an ideological authority including the whole Islamic ummah, those who lived inside his realm as well as those living outside, under alien political authorities, including those peoples ruled by the European imperialists. Hence the comparison with the Pope who has also authority on people he does not govern, but hence also the fear of the Imperial powers having at least an idea that in Islam, everything "religious" could quite quickly turn out to develop political energy and dynamics. Therefore, the notion of the ukbuwwah Islamizar could quickly mutate into a militant, albeit self-defensive ideology, namely, pan-Islamism.

This inherent energetic and dynamic dimension is usually linked with the notion of jibäd. Politicians usually do not bother about the theological definitions and explanations of the terms and notions they use, as long as they benefit their goals. Not so much by scholars than by lay people like journalists and intellectuals in the Muslim world, the 
rebellions or wars against expanding Western imperialist powers during the 19th and early 20th centuries therefore were styled as jihäd, now with the dominant meaning of "war of defense". In this meaning it had not directly a conceptual legitimization in the Islamic traditions, and also formally it did not meet with the requirements of the religious law to conduct a jibäd fi sabil Alläh. But it could quite well denote the emotional dimension inspiring these belligerent encounters. Although Sultan Abdülhamid II refrained himself from using the notion of jibäd, he did not tire to remind the Muslim World that he was their caliph and therefore the highest authority in the Islamic religion.

In classical Islam, the caliph had held a political and legal position linked to his role as ruler (or sultan), and as "Commander of the Faithful" (amir al-mu'minin) this role materialized in his capability of establishing and maintaining the integrity of the Där al-Islam, the Islamic Empire. This political role had already eroded considerably during the Abbasid caliphate and never recovered again. The proper religious authority, however, was in the hands of the Shaykh al-Islam, in Turkish Seh-ül-Isläm.

Usually the Seh-ül-Islam functioned as mufti of Istanbul before his installment as Seh-ül-Islam, and as such he was also the legal adviser to the Sultan. Of course, a mufti is no judge! In the constitutional composition of the Ottoman State, the Şeh-ül-Islam maintained a position similar to that of the other leaders of religious communities (millet) like the Patriarchs of the different Christian Eastern rites, or as the Hakam of the Jewish community. He was the head of the Islamic millet, of which the caliph, as a Muslim, was also a member. This gave him considerable power, and it is understandable that the sultans and caliphs of the 19th century, trying to upgrade their "spiritual," or nominal authority among the whole of the Islamic community, stripped the Seh-ül-Islam of most of their power in the constitution of 1876. This vacuum of authority on the spiritual side was filled in, at least partly, by the Sultan's understanding and practicing of the role of the caliph, and he expanded this understanding to the Muslims living outside of his sultanate. It was this "new" understanding of the caliphate which alerted the imperial powers and made them very sensitive and oppressive against any encouragement of pan-Islamist ideas, because such mixture of political and religious/ideological conceptions had always proven to be of highly explosive potentiality. 
Even if the caliph was no match for them for the time being, that could change very quickly.

One problem still has to be mentioned which the Ottoman sultans were facing with regard to their claim to the caliphate. They were neither members of the $\overline{A l}$ al-bayt nor the Quraysh in general, thus lacking, at least in the minds of traditionally well versed and convinced Muslims, a major precondition to become caliphs. How sensitive this point has been will be shown in the next paragraph which deals with Jamāl al-Dīn al-Afghānī and his tense relations with Abdülhamid II, both vocal and practical propagators of Pan-Islamism.

\section{Jamāl al-Dīn al-Afghānī and Abdülhamid II: Propagators of Pan- Islamism}

Jamāl al-Dīn al-Afghānī (1837/8-1897, henceforth "Jamaluddin”) is one of the outstanding personalities in that wing of the Islamic Resurgence that turned radical and militant after the experience of the Mutiny in 1857 and its aftermath. ${ }^{2}$ It is not quite sure whether Jamaluddin in his young years had been an eye-witness of the atrocities committed in Delhi in 1857. It is sure, however, that these events marked his attitude towards the British until the end of his life.

After the destruction of the Moghul Empire many observers expected the newly rising Kingdom of Afghanistan to take its place as the third of the still existing great Islamic Empires. After the death of the old king, Amìr Dūst Muh. Khān in 1863, a war of succession broke out among his sons, and from 1866-1868 Jamaluddin appears in Afghanistan as a supporter of A'zam Khan, one of the pretenders to the throne. Jamaluddin advised him strongly not to ally himself with the British who wanted to penetrate into Afghanistan, but to approach Russia who resented the growing influence of the British close to its own central Asian areas of influence. The preference of Jamaluddin to Russian imperialism is quite astonishing because at that time, Russia

\footnotetext{
2 The nisba "al-Afghānì" in his name gave cause to many disputes, cf. the introductions to most of the books written about him, but also the interpretations of his personality and role in history are very controversial. See, for example, Nikki R. Keddie, $A n$ Islamic Response to Imperialism. Including a Translation of the "Refutation of the Materialists", from the original Persian (Berkeley and Los Angeles: University of California Press, 1968); Homa Pakdaman, Djamal-ed-din Assad Abadi dit Afghani (Paris: Maisonneuve et Larose, 1969); Prof. Dr. HAMKA, Said Djamaluddin al-Afghany (Djakarta: Bulan Bintang, 1970). See also Albert Hourani, Arabic Thought in the Liberal Age 1789-1939 (London: Oxford University Press, reprint 1967), pp. 103-129.
} 
had already annexed a number of territories formerly belonging to the Ottoman Sultanate or being allied with it, in Southeastern Europe and around the Black Sea as well as to the East of the Caspian Sea. This soft attitude towards Russia should later become one of the main reasons for his tense relations with the Persian Shah as well as with the Ottoman Sultan. It is also astonishing that the religious motivation behind Russia's policy against the Islamic World did not attract Jamaluddin's attention, being himself considered also as a religious reformer of Islam who, like other politically active revivalists, included more and more the struggle against "the infidels", i.e. the imperial powers as being Christian, into their agenda.

After A'zam Khan's defeat by his younger brother who was supported by the British in 1868, Jamaluddin was expelled from Afghanistan, and finally he settled in Egypt from 1871-1879. When he arrived there, the Suez Channel, built by the French, just had been opened in 1869. This caused the British to appear in Egypt because of their interest in the channel which shortened the way to their Eastern colonies and particularly the "pearl" among them, India, immensely. This led to political turmoil in Egypt itself, and the crisis accumulated with the bankruptcy of the State in 1875. The Egyptian shares of the channel had to be sold to the British who thus took virtual possession of it, and this step increased their political and military influence in the country considerably. In 1879 they urged that the khedive ${ }^{3}$ Ismail be replaced by the young Taufiq who had to submit himself to British orders. An unsuccessful rebellion of egyptian military leaders against the British command, led by 'Urabi Pasha, in 1882 was the last-futileattempt to reduce British dominance.

This is, in short, the historical background of Jamaluddin's sojourn in Egypt. Being not allowed to give lectures at al-Azhar, he assembled a group of interested students, intellectuals, politicians and others interested including 'ulamä' from al-Azhar like the young Muhłmmad 'Abduh (1849-1905) in his home where he held regular sessions to

\footnotetext{
3 Khedive was the title of the Egyptian rulers after they were recognized by the Ottoman Sultan as local rulers under his suzerainty. In 1922, based on a new constitution and the disappearance of the Ottoman Empire after Turkey was proclaimed a republic in the same year, the title was changed to "king". The British kept their shares until the channel was nationalized by Gamāl 'Abd an-Nāsir (Nasser) in 1956, which led to the "tripartite aggression" of Britain, France and Israel against the Egyptian Republic.
} 
discuss political and societal problems of the day or to present his ideas about the urgent need of a mental and particularly societal renewal of the Islamic ummah and the means to achieve it, namely by joining the Pan-Islamist movement. One of his focuses was to strengthen the awareness of ukbumwah Islamizath and the obligation of all Muslims to resist imperialism, but at the same time to reconstruct the Islamic ummah and its society, starting with a radical renewal of their understanding of Islam and the methods of their religious, scientific and social patterns of thought. He demanded a rational approach towards religion, its interpretation and application. His lectures left strong impressions in the minds of the younger generation, among them, besides 'Abduh, also 'Urabi Pasha, Za'd Zaghlūl who became a leading Egyptian politician immediately after World War I, and even the then crown prince Taufiq. The relation with Taufiq, however, proved to be ambiguous, because after his ascending to the throne and 'Urabis futile rebellion, Taufiq knew the persons behind the uproar and could easily take measures against them. On the instigation of the British, Jamaluddin was expelled already in 1879, shortly after Taufiq replaced Ismail, 'Abduh was expelled from his homeland in 1882 and 'Urabi was exiled to Ceylon (Sri Lanka) the same year.

Again Jamaluddin had experienced the realities of British imperialism which underlined his already existing antipathy. Nevertheless, with the consent of the British government but with strict regulations with regard to his moves, he went to India where he spent some years without major agitation. There he took the time to write, in Persian, his booklet about the sect of the "naicer", a term which appeared at that time (derived from "naturalist") to denote a trend in Western thinking which linked itself to the findings of the natural sciences and particularly biology, and which "Abduh rendered in his Arabic translation as dahri ("materialist", "nihilist"). In this booklet Jamaluddin criticizes sharply those thinkers of the East, particularly Muslims, who let themselves be inspired by Western materialist thinking as expressed in the ideology of "naturalism" or "Darwinism" which rejects the notion of a Creator and deduces everything in the universe to the rule of evolution. One of his main targets was (Sir) Syed Ahmad Khan who tended to follow to some extend the premises of Charles Darwin's philosophy. Jamaluddin however, like a number of Hindu thinkers at the same time, 
denounced this philosophy as another attempt of Western thinking to undermine the "spirituality" of the East with pseudo-scientific theories which attract the attention of simple minded people. For Jamaluddin, it only showed another side of Western imperialism, this time in terms of mental and intellectual occupation, and again he urged the Muslim community to unite into one strong brotherhood in order to rediscover and defend its own identity and values.

With this booklet, the pan-Islamist movement received a new dynamism in that the focus switched from the predominant political agitation to include also societal, cultural, and spiritual aspects. It remained, however, his only independent publication. A series of articles, pursuing this topic, he published later, when he lived for few years in Paris, in the journal Al-Urwat al-Wuthqà (cf. Supah 2:256 and 31:22) which he edited together with 'Abduh who had joined him in Paris in 1884. In this journal both and some other friends of them presented their revivalist and reformist ideas, and particularly Jamaluddin, also his political views, while 'Abduh focused on actual methods of Qur'anic interpretation, a reform of the legal thinking in Islam, and a reconstruction of the Islamic educational system.

This journal was short-lived. It only appeared for approximately half a year in 1884. It then had to close down because of British intervention. ${ }^{4}$ This quick reaction by the British and other colonial powers like the Dutch shows, however, how influential in the Islamic World even to Southeast Asia this journal had become in such short a time. The notion of pan-Islamism had become a symbol to warn that forces are on the move which at some time may run out of control, thus endangering the whole construct of the Imperialist world order. In some of his articles as well as through direct mediation through some of his friends in Istanbul Jamaluddin had touched a plan to work for an alliance between the Ottoman Empire, Afghanistan and Persia. For the Ottoman Sultan Abdülhamit II, such a plan met with his deepest hopes, but the Shah was not enthusiastic with a vision to see Tehran "reduced to a vassal" to the Sublime Porte. ${ }^{5}$ Since 1501, the Shi ithna $>$ asharizarb was proclaimed the official Islamic rite in Iran.

${ }^{4}$ Cf. Deliar Noer, The Modernist Muslim Movement in Indonesia 1900-1942 (SingaporeKuala Lumpur: Oxford University Press, 1973), p. 32 fn. 4.; Pakdaman, Djamal-ed-din Assad Abadi dit Afghani, pp. 93-106.

${ }^{5}$ Pakdaman, Djamal-ed-din Assad Abadi dit Afghani, p. 106 f. 
This had led to some amount of isolation experienced by the Persians in the Islamic World. In his understanding of pan-Islamism, Jamaluddin had included the Shi without any prejudices. Thus, on one side the Shah may have seen in Jamaluddin a combatant in efforts to approach the Sunni part of the Islamic community. On the other hand the Shah was suspicious about the aims of Sultan Abdülhamit II and his way of propagating pan-Islamism, fearing that finally the Sultan might play a dominant role reducing others to subordinate positions.

Other political activities in Paris involved him in the Mahdi crisis in Sudan. Jamaluddin mentioned the Mahdi as one of his former disciples in Cairo. ${ }^{6}$ For him, the sole solution would be a withdrawal of the British from both, the Sudan and Egypt, for which he also hoped to find some support from the French government.

In mid-1885, on the invitation of S. Wilfred Blunt (1840-1922), an English poet and stern sympathizer with anti-imperialist movements, particularly pan-Islamism and the revolt of the Mahdi in Sudan, Jamaluddin moved to London where he could meet with various British politicians to discuss mainly the situation in the Sudan and possible solutions. There was some hope that his relations with the Mahdi might be helpful to find some acceptable way out of the crisis. When he was asked by Randolph Churchill about the prospects of reconciliation between the British and the Islamic world his answer was short and clear: the British should leave Egypt, and they should support an alliance between Afghanistan, Persia, and the Ottoman Empire. This option for his pan-Islamic agenda was clear, but it showed also that the British had to choose either to obtain friendship with the Islamic World, or to maintain their imperialist strategy. Thus pan-Islamism proved to be the ideology directly confronting the imperial interests. There was no bridge between both. This messaged was heard, and henceforth measures to be taken against the spread of pan-Islamism ranged on the top of the agenda of the imperialist powers.

From London Jamaluddin went to Persia where he obtained a warm welcome by Nasiruddin Shah (regn. 1848-1896). The Shah, however, because of his despotic rule and little care for the welfare of his people, was much despised, by the people and by the religious

\footnotetext{
${ }^{6}$ Pakdaman, Djamal-ed-din Assad Abadi dit Afghani, p. 91, where she quotes a letter of Jamaluddin's.
} 
scholars. Jamaluddin opted with their grievances and favored a change of rule, maybe establishing a republic. Thus his relations with the Shah quickly deteriorated although openly they continued to exchange polite messages. Finally with the permission of the Shah Jamaluddin left Persia in 1887 "for Europe".

His destination was Russia. Two years he spent in St. Petersburg where he met also with some political personalities from the entourage of the Tsar. The Russian government saw with increasing disdain the growing influence of Britain particularly in the South of Persia, but also its increasing domination of the finances and economics throughout that country. With the support of Jamaladdin the Russians obviously hoped to convince the Shah to readjust his pro-British policy. As some kind of intermediary, Jamaluddin returned to Tehran in 1889 and again was welcomed by the Shah.

But finally, the view points and interests of both were too much opposed to each other. For the Shah, Russia was the great threat in the north, not so much Britain. With a British merchant, the Shah had just prolonged a treaty giving concession to sell the complete production of tobacco, which among other things meant that big areas of land could not be used any longer to grow grains and other food-staff because they had to be planted with tobacco. This caused a remarkable shortage of food supply, and the reaction of the Persian religious scholars (mujtahid or Molla) was a fatwa eclaring the consummation of tobacco as horam; it may be remembered that at the beginning of the same century, the Wahhabis in Arabia had issued a similar fatwa fyainst tobacco, albeit for other reasons.

Jamaluddin supported the people and the scholars, thus evoking again the anger of the Shah who earned good benefit from this and other deals with the British. With regard to the Shah's concern about Russia, Jamaluddin again was not very responsive. He may have envisioned that both, Persia and Russia, could also be allies in his antiBritish agitation. In 1891, Jamaluddin was expelled by the Shah. In 1896, Nasiruddin Shah who had become extremely unpopular and tyrannical, was killed by a follower of Jamaluddin.

Via London where he stayed a few months, Jamaluddin traveled, on the invitation of Sultan Abdülhamid II, in 1892 to Istanbul where he stayed for the rest of his life. A first invitation which reached him in London, he refused. The second invitation used stronger words: Not following the orders of the Sultan means to disregard the orders of 
God! ${ }^{7}$ Also the British wanted him out of their country because of his anti-Persian agitation which strained their relations with the Shah. Additional alarm caused a note from the British consul in Cairo transmitting the French translation of a secret paper, compiled by Jamaluddin in London, designing an alliance between Afghanistan and the Ottoman Empire, leaving it to Persia to join in spite of the Shah's resentments or to see himself isolated amidst the Islamic World.

Now, with accepting the Sultan's invitation, the ruler who used pan-Islamism to strengthen his religious authority among the Islamic ummah, and the propagator of pan-Islamism who wanted to transform it into a forceful movement against foreign imperialism in Muslim territory, came to meet each other. But again, their mutual expectations did not meet. The Sultan was suspicious whether Jamaluddin's support for him was sincere. There were rumors that during his short sojourn in London, Jamaluddin had met with some Arab shaykhs and 'ulamä' to discuss the possibility of establishing an Arab caliphate. It does not seem impossible that such a plan might have obtained some support from the British. On one side, such a move would weaken the position of the Ottoman Sultan, on the other side would an Arab caliph without own territory but only as an idealistic symbol and with some amount of spiritual authority be of no threat to the imperialist powers, and therefore such a caliphate which had no chance to develop any political power could be accepted by them.

Jamaluddin's position is not quite clear. It is difficult to imagine that he, who consistently linked the caliphate to political action, could accept a mere symbolic caliphate. Sultan Abdülhamit II, however, was alerted. He knew about his political weakness and therefore had to resort in one or another way to an idealistic understanding as well, as suggested the Constitution of 1876. To disperse the Sultan's suspicion, Jamaluddin discussed with him a plan to invite a congress of 'ulama', from most parts over the Islamic world to discuss the question of the caliphate. Such a congress could strengthen the position of the Sultan. But the Shah refused, and the congress did not take place. ${ }^{8}$ After that Jamaluddin busied himself again with his agitation against the Shah. Since he also approached non-Muslim Persians to join forces in order to free Persia from the Shah, a public discussion was launched against

\footnotetext{
7 Ibid., p. 169.

${ }^{8}$ Ibid., p. 172.
} 
him questioning his religious credibility as a Muslim. ${ }^{9}$ New trouble in his relation with the Sultan emerged when the new khedive of Egypt, Hilmi, paid a visit to the "Sublime Porte" in 1895.10 His demand to meet with Jamaluddin was rejected; therefore they met in secret, observed however by the Sultan's secret police. Abdülhamit II was obviously afraid that an Arab caliphate might be discussed again. But when after the murder of Nasiruddin Shah the Persian government demanded the extradition of Jamaluddin, the Sultan refused. One year later, in 1897, Jamaluddin died in Istanbul because of cancer. Rumors that he might have been poisoned on the order of the Sultan were repelled by medical records.

A decisive part of his legacy was his using religious (Islamic) language for political tools, thus supporting the notion of Islam as "din wa dawlab", as religion and state, or the merger between politics and religion, without questioning the origin of such a construct. ${ }^{11}$ The symbol for this was the caliph as the supreme leader of the Islamic ummah, but here the problems occur: although tradition would urge him to be the religious and political leader in one, reality confined the role of the actual caliph to that of a weak politician and a questionable symbolic focus of orientation thus leaving the concept of panIslamism pending somewhat in the air - to the relaxation of the imperial powers. Remains the question: what about jihs $\bar{a}$, the third element in this traditional concept of one ummah under one amir almu'minin?

\section{The Promulgation of Jibac. From Pan-Islamism to Anti- imperialism}

Before coming back to such a question, some other political developments have to be considered. The proclamation of the German Kaiserreich in 1871 brought another actor to the stage of international politics. Germany, until then divided into a number of kingdoms and principalities, had played no role in the colonial and imperial history, having left the imperial tradition to Austria. When the third Kaiser,

\footnotetext{
${ }^{9}$ Keddi, An Islamic Response to Imperialism, p. 33 f.

$10 \mathrm{Al}$-Ba $\gg$ al' $\mathrm{A}$ as the common reference code for the sultan's government quarters in Istanbul, referring to one of its entrance gates, like the "White House" is a symbol for the US-president's residence.

11 To elaborate on this question would need more space.
} 
Wilhelm II (regn. 1888-1918), initiated a greater presence of Germany among the great powers, the cake of territories which could be colonized was, except of some greater areas in Africa, already distributed, particularly in the Islamic World. He therefore had to find a place on the world market, particularly for the products of the quickly emerging German industry.

The Kaiser found his partner in Sultan Abdülhamit II. The Sultan, weekend after the Russian-Ottoman war of 1877/8, accepted German assistance to rebuild his army. Other help was offered and accepted to develop the infrastructure, including the Baghdad railway on which the British were already working. This double assignment led to a lasting conflict between Britain and Germany. The assistance of Germany helped the Sultan to repay his debts to Britain and France who until then had planted a lot of capital and expected the repayment of their interest.

A special occasion to underline the close relations between the Sultanate and the Kaiserreich was Kaiser Wilhelm II's visit to Istanbul and the Middle East, particularly Syria and Palestine in 1898. In a speech he delivered at the tomb of Sultan Salāh ad-Dīn (Saladin) in Damascus the Kaiser said: May the whole Islamic community, whereever they live, accept this oath that the German Emperor always will be their friend. ${ }^{12}$ The Sultan as well the Kaiser used every chance to appear as magnificent rulers, representing to some degree the glory of the East and the power of the West, not forgetting the religious aspects in both of them. Historical reminders should underline their encounter: During the friendly exchanges between Charlemagne as the first emperor of the Franks and the caliph Harūn al-Rashīd, the caliph is said to have once offered to the emperor to become the protector of the Christians residing in the Middle East, especially those living in the Holy Land (Palestine). That offer was, of course, unpractical at that time. For Kaiser Wilhelm II this idea seemed to be attractive, seeing himself in the footsteps of Charlemagne as prince of the Christians, and as protector of the Christians in that area, but with one decisive difference with regard to the later developments during the crusades: he would come as an ally of the Islamic community, not with an army

12 Quoted in Matti Schindehütte, Zivilreligion als Verantwortung der Gesellschaft. Religion als politischer Faktor innerbalb der Entwicklung der Pancasila Indonesiens (Hamburg: Abera, 2006), p. 72. 
to fight against them. If fight should become necessary, then together with them against their enemies.

The visit of Kaiser Wilhelm II had a great impact, although the interpretations given by the Ottomans and the Germans may differ to some degrees. But that was not expressed at that time. If the Kaiser accepts the protectorate over the Christians offered to him by the Sultan, than in the Sultan's understanding he would become a kind of vassal. Especially after the tanzimät, the Christians like other nonMuslims had acquired a kind of citizenship. Therefore, to call the Kaiser a protector of the Christians in the Middle East - who are and remain citizens of the Sultanate - and accept this role as a sign of friendship can only mean that the Kaiser accepts the Sultan's superiority in this matter. As Sultan and Caliph, the Ottoman ruler remains the souvereign of the Oriental Christians. No wonder that Abdülhamit II praised the Kaiser's policy as strengtening his position on the stage of international politics.

And support was also given to the pan-Islamist ambitions of the Sultan. In the years before World War I, it became more and more apparent that the Sultan's enemies, or the opponents of pan-Islamism, became, with few exceptions like the Netherlands, the enemies of the Kaiserreich. Supported by German oriental scholars like Max von Oppenheim, respected author of some books about the Bedouins of the Sahara and at that time working at the German consulate in Cairo, and others the German diplomats in the Middle East were encouraged to support the Sultan's propagation of pan-Islamism and his role as caliph in it. Even the option to call for a jihäd in the case of a war should be stimulated and supported. If it succeeded and the Muslim subjects of the imperial powers raise their arms against their "infidel" rulers, than not only the case of Islam could take a positive turn. Simultaneously it would decisively weaken the enemies of Germany and their allies, and thus strengthen the whole anti-imperialist front. For the Turkish leadership there was no doubt that in case of a victory of the imperial powers (mainly Britain, France, and Russia) the Ottoman Sultanate would be divided and thus terminate its history, while a victory of the Germans and their allies would lead to German economic hegemony. ${ }^{13}$

${ }^{13}$ Josef Matuz, Das Osmanische Reich. Grundzüge seiner Geschichte, 2nd ed. (Darmstadt: Wissenschaftliche Buchgesellschaft, 1990), p. 263. 
In August 1914 the war broke out and the Sultanate was drawn into it on the side of the Germans. In November of the same year, Sultan Mehmet V Reşat (regn. 1909-1918) as caliph, urged by his German advisors and particularly the Kaiser, demanded that the religious authorities proclaim the jibäd, what they did.

But the reaction in the Islamic world was close to zero. The Young Turks who had taken over the government in the Sultanate after a coup d'état and the de-throning of Abdülhamit II in 1909, had made themselves enemies to nearly all non-Turk ethnic groups, Muslim or not, living in the multi-ethnic Sultanate. Arab nationalism (or alqawmizarb al-arabizab) had already been the answer of the Arab intellectuals throughout the "Fertile Crescent" in the 1880s when Young Turkism started its development. The Sharif Husain of Mekka, protector of al-Haramayn, bluntly refused to support the idea of a jibäd against the British, but he pursued already another agenda. In 1916, supported by some British diplomats in the Middle East who opted against too close relations with the French, he and his sons started the "revolt in the desert", after they were promised to rule over an Arab kingdom including the former Arab provinces in the Ottoman Sultanate. Only after the Bolshevik revolution in Russia in 1917 and their publishing the secret imperial archives the Arabs realized that they were cheated. The Sykes-Picot agreement between Britain and France which later was implemented, proposed a division of the Arab areas into spheres of British and those of French interest. When the legendary secret agent T.E. Lawrence published his records about the "revolt in the desert" under the title: The Seven Pillars of Wisdom, the Arabs called it The Seven Pillars of Treason.

Politically, the declaration of the jibäd was a flop. But it led to a heated discussion among European scholars on each side of the European front. The Germans, as mentioned already, not only supported the Sultan in this matter, they also justified his option for pan-Islamism as a proper tool to defend his position and, in his capacity and responsibility as caliph, to lead the Muslims in their struggle to free themselves from the rule of the "infidels". C.H. Becker puts forward the following remark:

If Turkey at present in its foreign policy uses pan-Islamism, it justifies it as a means of self-defense. Britain and Russia put pressure on Turkey because they want to enlarge the territories under their rule, and France tries to bring Turkey 
under its financial control. ...Millions of Muslims feel themselves suppressed by the great powers. ...If Turkey underlines the spiritual bond which unites all Muslims, then it weakens the European powers who rule over so many Muslims. ...There are people who criticize the use of a common religion (for political goals). But what did Britain, France and Russia do during the last century? Their common interests were also their main motivator while enlarging their influences on Turkish territory. ... They used religion in their policies for imperial goals. Turkey uses it in order to defend itself and to safeguard its existence. ${ }^{14}$

Becker made some efforts to disperse suspicions that the Ottoman caliph might use jiha $\bar{a} d$ in the same sense, a suspicion nurtured by the imperial powers, including the Netherlands whose colonial politicians were advised in matters related to Islam by the outstanding Dutch oriental scholar Christiaan Snouck Hurgronje whom Becker regarded as one of his teachers. But Becker underlined that the present understanding of jib $\bar{a} d$ had changed and that the Ottoman sultan and caliph uses jiha ad, his title as caliph, and pan-Islamism as the inspiring ideology to join forces in fighting the imperialists in order to safeguard the continuation of his empire and to enable him to reconstruct the glory of the ummah and of the Islamic civilization. Becker acknowledged that such policy and every appeal to Muslims who live under non-Muslim governments would be considered as interference into their "internal affairs" by the imperial powers.

Becker obviously tried to minimize the "pure" religious dimension in the use of pan-Islamism and the understanding of the caliphate as maintained by the last Ottoman sultans. The sultan, he explains, is not a Pope but a secular ruler with the shariah, as "holy Law", at his side. However, not the caliph but the Seb-ül-Islam is the highest authority to interpret the shari $i^{-} a h$, and this did not change even after the authority of the Şeb-ül-Islam declined during the reign of Abdülhamit II. The shari ${ }^{-} a h$ even in the few sections of social life were it was maintained

14 Carl Heinrich Becker, "Islampolitik," in: Ibid., Islamstudien, vol. II (reprint Hildesheim: Olms, 1967): pp. 310-332, pp. 316-317. This article appeared for the first time in 1915; cf. also Matti Schindehütte, "Religion als politischer Faktor. Erinnerung an die Dschihadisierung der deutsch-türkischen Waffenbruderschaft," in Zeitschrift für Mission 33 (2007), pp. 10-20. C.H. Becker (1876-1933) was in his time one of the outstanding German oriental scholars. 
after the tanzimāt is not a written law, as Becker explains. It is, moreover, an ongoing discourse about the obligations of a Muslim, and the "Islamic character" of the Islamic revival, including panIslamism, is rooted in this dynamic process, not in a formalistic "islamic" structure of the rule. Therefore, and this is Becker's intention, the traditional notions related to the caliphate, jih $\bar{a} d$ and panIslamism do not inspire anymore the policy of present day Ottoman rulers but have been reshaped essentially to meet the present needs.

This argument was not accepted by Becker's opponents. They might agree with him that these notions were considered to be out of date by most of the Muslims, but they would add that the majority of the Muslims would also feel no inclination to revive them knowing how easily they could get out of control and ignate fanaticism. The poor reaction in the Muslim world on the proclamation of the jiba $\bar{d}$ in 1914 would support their judgment. Jihäd was used in a general sense in newspapers using Oriental languages during the Balkan wars, and during Italy's invasion into Libya, as "wars of defense", but without connection to the caliph or pan-Islamism, and without any fatwa $>0$ proclaim it. Therefore, there was no Islamic legitimation for these jihäds. The jihäd proclaimed in 1914 met the formal requirements, but its lengthy explanation did not convince that it was for the need of the Islamic umma. Its focus stressed the continuation of the Ottoman Sultanate. As such it was not a jihäd generally supported by the Muslims and, moreover, was urged for by a non-Muslim ruler. Therefore, the Entente-powes called it bluntly a jihäd made in Germany, more or less imposed even on the caliph who had hesitated for some while before agreeing to demand its proclamation. But with this background, the jihäd had lost any similarity with its medieval understanding as being strictly associated with Islam only. How much its actual understanding was already determined by general political considerations came to the open by a somewhat cryptical event.

In the text of the proclamation the Netherlands were mentioned among those who ruled unjustly over Muslims. ${ }^{15}$ The definition of such a status where the Muslim subjects made their peace with a nonMuslim ruler is termed as, according to this paper, "gebied der

15 I refer to a Dutch translation presented by C. Snouck Hurgronje, Verspreide Geschriften, deel III (Bonn - Leipzig: Kurt Schroeder, 1923): pp. 31-351; p. 342. 
goddeloosheid" or daral-kufr. ${ }^{16}$ But the Netherlands were also in peace with the Caliph. So, half a year later a "Correction" was distributed underlining that the jibäd was only declared against those who were in war with the caliphate. Therefore, the Muslims of the Netherlands' Indies were excluded from this call to revolt. ${ }^{17}$

Among the scholars outside of Germany who vehemently denounced the German jibäd-policy as a playing with the fire, or trying to "unearth the mummies buried already at the end of the middle ages," was Christiaan Snouck Hurgronje (1857-1936). ${ }^{18}$ In an emotional article published also in 1915 in a New York newspaper the United States had at that time not yet declared war against Germany - under the heading "Islam made in Germany" he first praises the Young Turks who had dethroned the "despot" Abdülhamit II in 1908 and restored the constitution, but because of the enmity of the imperial powers, the Young Turks were forced to revive despotic rule. "Also the fetish of the caliphate had to be exhumed again from the museum of antiquities where it had temporarily been stored. As to the idea of jihad, which was so closely connected with it, the European powers took care that it was not forgotten. Turkey was continually forced to a jihad". ${ }^{19}$ Thus Snouck Hurgronje refuted the policy of the imperial powers that based it on their erroneous assumption that the Muslims consider the caliph as their highest authority in religious matters. That assumption he calls "nonsense", but this nonsense is the basis of the imperial powers and their attitude towards the Ottoman sultan and caliph, and also the Germans adopted it and justified their

\footnotetext{
${ }^{16}$ Ibid., p. 345. According to other Islamic traditions, it might have been called also das al-salarr. But "peace" was not the topic of the day.

17 Ibid., p. 352 f.: "Verbetering eener vergissing".

${ }^{18}$ From among the many articles on C. Snouck Hurgronje and his attitude towards Islam, I just want to mention a few: H. Aqib Suminto, Politik Islam Hindia Belanda (Jakarta: LP3ES, 1985); Hamid Algadri, C. Snouck Hurgronje. Politik Belanda terhadap Islam dan Keturunan Arab (Jakarta: Sinar Harapan, 1984); Harry J. Benda, "Christiaan Snouck Hurgronje and the Foundations of Dutch Islamic Policy in Indonesia," in Ibid., Continuity and Change in Southeast Asia, Collected Journal Articles of Harry J. Benda (New Haven: Yale Univ. Southeast Asia Studies, Monograph Series No. 18, 1972); and Taufik Abdullah's short but informative "Introduction" to the translation of Hurgronjes paper Islam di Hindia Belanda (Jakarta: Bhatara, 1973) pp. 5-12.

19 The whole article "Islam made in Germany' also in Verspreide Geschriften, deel III, pp. 259-284, quotation on p. 268.
} 
policy by it. While the imperial states allied in the "Entente cordial" (Britain, France, later Russia until the Bolshevik revolution in 1917) aimed finally to destroy the Sultanate with its decaying power structures which only could function under despotic and unscrupulous rulers like Abdülhamit II and his successor Mehmet V Reşat. Germany, on the other side, was forced to ally itself with these rulers who were hated and rejected by their people, and therefore as well was forced to support the medieval structures of the past history of Islam which they kept alive and strengthened them for their own benefit. "I may already now foretell with certainty that within a not very long time, a number of German writings will testify that also in Germany indignation has been aroused by the despicable game that is being played with the Caliphate and the holy war"'. ${ }^{20}$

For Snouck Hurgronje, the corpus of Islamic thought had been developed in three main areas: (1) pure religious (dogma, worship), (2) social or societal, (3) political. ${ }^{21}$ While he accepted numbers (1) and (2) whole-heartily, he also urged the colonial government to support its development under the premises of "freedom of religion". The third one, however, whose actual expression he linked particularly with panIslamism as a fanatical and antiquated movement, should not be tolerated by any pretext. Stressing the neutrality of the Netherlands in the current political conflicts in Europe and his personal good relations to Germany and German scholars, he vehemently rejected Becker's option for a cooperation with either the propagators of pan-Islamism as an anti-imperial ideology or the politicians who fight a jibäd under its banner like the Turkish government supported by the German Kaiser, and admitted that in that point, the Dutch interests met with those of the other imperial powers.

Becker, in another article, replied to the allegations of Snouck Hurgronje. 22 The arguments of both of them still deserve sincere

\footnotetext{
${ }^{20}$ Ibid., p. 282.

${ }^{21}$ Hurgronje frequently made this point, usually linking it with his vision of a "national synthesis" between the Dutch and their Indonesian subjects, particularly the Muslims, cf. e.g. Abdullah, "Introduction," p. 9.

22 C.H. Becker, "Die Kriegsdiskussion über den Heiligen Krieg (1915)," in Islamstudien, loc. cit., pp. 281-309; A comprehensive study, based on archive material, about the German Imperial policy towards Islam in the $19^{\text {th }}$ and early $20^{\text {th }}$ centuries, has recently been published by Wolfgang C. Schwanitz, Djihad made in Germany. Deutsche Islam-Politik. im 19. und 20. Jabrbundert (Berlin: Trafo, 2005), a second edition is in preparation.
} 
attention, not at least because they help to highlight some of the basic roots of conflict even in the present confrontations between "the Islamic" and "the Western" worlds. Only few analyses have been presented until now who look behind the surface and reveal the intrigues and manipulations, but since their findings do not support the interests of the rulers even nowadays, they usually are withheld from public attention. In some concluding remarks the reaction among the Muslim public itself on the caliphate, pan-Islamism and jihäd may just be summarized. It must be remembered, however, that the Ottoman Sultanate, together with the German Kaiserreich and their allies, were defeated in the war, and the situation after that was determined by the , Entente, without the Russians, however, because the Bolsheviks after their revolution had no intention to continue the "Byzantine" politics of the Tsar. A map of Turkey how the Ententepowers designed it in the Treaty of Sèvres in 1920 may be seen in the book of Josef Matuz. ${ }^{23}$ Under pressure, it was accepted by the Sultan, but it was rejected by the Young Turks, of course.

\section{Towards Inclusive Politics: The Case of Indonesian Islam}

As expected, the Entente dismantled the Sultanate and, according to the doctrines of the American President Wilson about every people's right of self-determination, reduced Turkey to those areas where, according to their perception, ethnic Turks were living, that means basically only in central Anatolia. The Young Turks or "Kemalists" (called after General Mustapha Kemal, later "Atatürk"), now in open defiance to the sultan, reacted. After a war with Greece, Istanbul with Eastern Thracia around Edirne on European soil was "rescued" for the Turks. Before that, the Seh-ül-Islam, on the instigation of the Caliph, had issued a fatwa >leclaring jibäd against the rebels. The mufti of Ankara, however, supported by Anatolian 'ulam $\bar{a}$ ' and lay-scholars, issued a counter fatwa In November 1922, the Kemalists abolished the Sultanate and in 1923 the General Assembly proclaimed the Turkish Republic (Türkiye Cumburiyeti). The Sultan and Caliph, Mehmet VI Vahideddin (regn. 1918-1922) was expelled, and Abdülmecit II installed as caliph, without any political power. ${ }^{25}$ In the peace treaty of

${ }^{23}$ Matuz, Das Osmanische Reich, p. 331.

${ }^{24}$ Matuz, Das Osmanische Reich, p. 272 f.

25 Matuz compares his position to that of the Abbasid "shadow-caliph" in Cairo after 1258. Matuz, Das Osmanische Reich, p. 277. 
Lausanne 1923, Turkey's sovereignty was restored over East-Thracia and the whole of Anatolia. In 1924, the caliphate was also abolished, again the caliph was expelled, and thus the history of the caliphate was terminated. In the understanding of the Young Turks, these steps meant the liberation not only of the Turkish Muslims, but of the Muslim community everywhere from an un-Islamic, actually Byzantine inheritance which had corrupted Islam and especially its ruling system and its civilization which was formed by it. ${ }^{26}$ Islam, thus purified now, should be related to the Turkish culture, and this interpenetration of both should be the basis of the new Turkish identity. To achieve this, no traditional 'ulama' are needed, and thus the concept of "laicism" was born, becoming the trade mark of Kemalism, called after Kemal Mustapha "Atatürk", the founder of modern Turkey in the tradition of the Young Turks.

The Arab official leaders reacted with some protest against the abolishment of the caliphate. But their own efforts to re-establish a new caliphate failed as well. Two pretenders for such a position emerged: one was the Egyptian king Fuad II - after a constitutional reform in 1922, Egypt was proclaimed to be parliamentary monarchy and the other one was 'Abd al-'Azīz Al Sa'ūd, the new ruler of Arabia and the Hijāz after he had defeated the Shariff Husain. Some scholars in the intellectual line of Jamaluddin like Muh. Rashīd Ridā, a disciple of Muhłmmad 'Abduh, defended vehemently the need of a caliph to give guidance to the ummah particularly in the present times of foreign suppression and internal turmoil caused by the influences of modern scientific and societal conceptions. They got, of course, some public support particularly by the rulers and conservative 'ulama', while others like 'Ali 'Abd ar-Rāziq, another disciple of 'Abduh's who also praised the steps of the Kemalists in Turkey as a step of liberation for Islam, were publicly condemned and stripped of their public positions. Amidst this controversy, 'Abd al-'Azīz called for an all-Islamic conference, a mu'tamar al-a al-Islantizith the main task to elect a new caliph. Since both pretenders obviously opted for the establishment of a new hereditary caliphate linked to their families, the enthusiasm for this endeavor was very limited and ended in no result. Until now the Islamic community survived without a caliph, and the

${ }^{26}$ Thus Ziya Gökalp, The Principles of Turkism (Leiden: Brill, 1968), p. 32 ff. 
Islamic ummah as a whole seems to be not much embarrassed by this state of affairs.

In Indonesia, the move of 'Abd al-'Aziz evoked also a controversy, but not so much about the caliphate as such as about the question of who was apt to represent the Indonesian Muslims at such a conference. The Islamic politicians, represented mainly in Serikat Islam, claimed this right for themselves, but they were challenged by the 'ulama' who understand Islam in the light of the traditions of abl alsunnah wa al-jamäah. No particular interest for the question of the caliphate was apparent. In their political and societal aspirations the Muslims of the Dutch colony in general joined forces with the religiously neutral nationalists, Muslims and others. In this alliance, and not under the banner of an ideology and political system whose roots in Islam are questionable, they finally achieved what they desired: national independence and unrestricted freedom to express and practice also their religious convictions.

It is noteworthy that the great majority of the Muslims whenever they have a chance to voice their aspirations, do not support a radicalization or even militarization of their religion. In the Middle East, most of the Muslims until now had no chance to voice their political or societal aspirations; therefore it is not appropriate to make general statements about their political will. It is worth noting however, that moderate Muslim writers in Indonesia very often quote from books written in Arabic by moderate Muslims in the Middle East. Muslims in Indonesia had this chance to opt for their political or societal aspirations in several general elections, and the large majority of them voted for politicians and parties who pursue an inclusive policy, reflecting the plural composition of their society.

\section{Conclusion}

A critical review of the history of the caliphate and its adjunct notions like "pan-Islamism" or rule over all Muslims, and jihäd to fight for it will reveal that ever since the dawlah of the Bani Umayya until the end of Ottoman dawlah, the ideal served very much the interests of the rulers and their dynasties and associates, either to legitimize expansion, or to justify resistance against others which finally served again their own interests. Not only the Ottoman sultans, but also Jamaluddin were very selective in defining the targets of jihäd. These were not only nonMuslim rulers-and even not all among them-; they could be Muslims as well if they opposed the ruler who identifies himself with God: his 
enemies are automatically the enemies of God! Maybe that is the deepest reason why finally, the majority of the Islamic ummah turned away from politicizing their religion and decided to use political tools to achieve political aims, even when defending themselves against iniquities and oppression. The mujähidūn in our days still have to face the same question: in whose interests are they fighting?. []

\section{Bibliography}

Algadri, Hamid. C. Snouck Hurgronje. Politik Belanda terbadap Islam dan Keturunan Arab. Jakarta: Sinar Harapan, 1984.

Becker, Carl Heinrich. "Islampolitik," in Islamstudien. vol. II. reprint Hildesheim: Olms, 1967: pp. 310-332.

-------. "Die Kriegsdiskussion über den Heiligen Krieg (1915)," in Islamstudien. vol. II. reprint Hildesheim: Olms, 1967.

Benda, Harry J. "Christiaan Snouck Hurgronje and the Foundations of Dutch Islamic Policy in Indonesia," in Harry J. Benda. Continuity and Change in Southeast Asia. Collected Journal Articles of Harry J. Benda. Monograph Series No. 18 New Haven: Yale Univ. Southeast Asia Studies, 1972.

Gökalp, Thus Ziya. The Principles of Turkism. Leiden: Brill, 1968.

HAMKA. Said Djamaluddin al-Afghany. Djakarta: Bulan Bintang, 1970

Hourani, Albert. Arabic Thought in the Liberal Age 1789-1939. London: Oxford University Press, reprint 1967.

Hurgronje, C. Snouck. Verspreide Geschriften. deel III. Bonn - Leipzig: Kurt Schroeder, 1923.

Keddie, Nikki R. An Islamic Response to Imperialism. Including a Translation of the "Refutation of the Materialists", from the original Persian. Berkeley and Los Angeles: University of California Press, 1968.

Matuz, Josef. Das Osmanische Reich. Grundzüge seiner Geschichte. $2^{\text {nd }}$ ed. Darmstadt: Wissenschaftliche Buchgesellschaft, 1990.

Noer, Deliar. The Modernist Muslim Movement in Indonesia 1900-1942. Singapore-Kuala Lumpur: Oxford University Press, 1973.

Pakdaman, Homa. Djamal-ed-din Assad Abadi dit Afghani. Paris: Maisonneuve et Larose, 1969. 
Schindehütte, Matti. Zivilreligion als Verantwortung der Gesellschaft. Religion als politischer Faktor innerhalb der Entwicklung der Pancasila Indonesiens. Hamburg: Abera, 2006.

Schindehütte, Matti. "Religion als politischer Faktor. Erinnerung an die Dschihadisierung der deutsch-türkischen Waffenbruderschaft," in Zeitschrift für Mission. 33, 2007: pp. 10-20.

Suminto, H. Aqib. Politik Islam Hindia Belanda. Jakarta: LP3ES, 1985.

Hurgronje, C. Snouck. Islam di Hindia Belanda. Jakarta: Bhatara, 1973.

Schwanitz, Wolfgang C. Djihad made in Germany. Deutsche Islam-Politik im 19. und 20. Jabrbundert. Berlin: Trafo, 2005. 